\title{
A Kinetic Study on the Oxidation of Ferrous Ion with Dissolved Molecular Oxygen
}

\author{
Masao IWAI*, Hiroshi MAJIMA** and Toshio IZAKI***
}

\begin{abstract}
The Kinetics of the oxidation reaction of ferrous ions with dissolved molecular oxygen in hydrochloric acid solutions have been studied at $\mathrm{FeCl}_{2}$ concentration of $0.2 \mathrm{~mol} \mathrm{dm}^{-3}$ or below, over the range of $\mathrm{HCl} \mathrm{3-6} \mathrm{mol} \mathrm{dm} \mathrm{dm}^{-3}$, and at various oxygen partial pressures and temperatures. It was found that reaction rate is expressed by the following expression.

$$
R=k K_{2} K_{2} a_{\mathrm{H}}+a_{\mathrm{Cl}^{-}} \cdot\left[\mathrm{Fe}^{2+}\right] \cdot p_{\mathrm{O}_{2}}
$$

The activation energies were found to be $78.2 \mathrm{~kJ} \mathrm{~mol}^{-3}$ in $3 \mathrm{~mol} \mathrm{dm}^{-3}$ hydrochloric acid solution

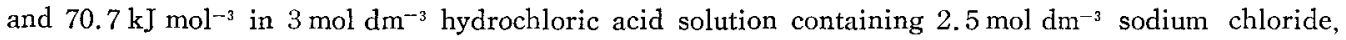
suggesting the overall reaction rate is controlled by chemical reaction steps. It has been presumed that the species of $\mathrm{HFeCl}^{2+}$ is thought to be controlled by the activities of hydrogen ion and chloride ion.
\end{abstract}

\section{Introduction}

Studies on the oxidation reaction of $\mathrm{Fe}$ (II) with dissolved molecular oxygen in hydrochloric acid solutions are interesting in connection with the treatment of waste liquors containing $\mathrm{Fe}$ (II) chlorides, which are commonly discharged from the processes, such as the pickling of iron and steel, the upgrading of ilmenite or pentlandite ores, the ferric choride leaching of copper concentrates, etc.

Much work has been carried out in the past on the autoxidation of ferrous sulphate solutions, but only a few papers are available for chloride systems.

Posner ${ }^{13}$ studied the kinetics of the autoxidation of ferrous chloride solutions and found that the reaction was of first order with respect to the concentrations of ferrous ion and dissolved oxygen but a more complex function of $\mathrm{HCl}$. On the other hand, Yano and his $\mathrm{co}^{-}$ workers ${ }^{2}$ reported that the reaction was of second order with respect to the concentration of ferrous chloride and of first order to the partial pressure of oxygen. Also, they stated that the reaction rate was independent of the concen-

* Department of Metallurgy, Toyoma Technical College (Toyama)

** Department of Metallurgy, Kyoto University (Kyoto)

*** Department of Metallurgy, Toyama University (Takaoka)

Key words: Autoxidation, Ferrous Ion, Hydrochloric Acid tration of hydrogen ion as far as the concentration of chloride ion was kept constant. Posner's conclusion of the effect of hydrochloric acid concentration on the reaction rate is quite different from that of Yano et al. The controversial conclusions by these previous investigators may be partly attributed to the difference in the experimental conditions employed.

However, it might be the easiest way to work kinetic experiments on the autoxidation of $\mathrm{Fe}$ (II) over the wide range of experimental conditions to reach a general understanding of its mechanism.

This study deals with the kinetics of the oxidation reaction of $\mathrm{Fe}$ (II) with dissolved molecular oxygen in hydrochloric acid solutions, aiming to get a better understanding of the reaction mechanism.

\section{Experimental Procedures}

The apparatus used for the oxidation experiments is shown in Fig. 1. The separable flask used as a reaction vessel was $1000 \mathrm{~cm}^{3}$ in volume.

In each test, $1000 \mathrm{~cm}^{3}$ of aqueous ferrous chloride solution, whose acid and chloride concentrations were adjusted with hydrochloric acid and various salts, respectively, was charged to the reaction vessel. The temperature of the water bath was controlled within $\pm 0.2^{\circ} \mathrm{C}$. The apparatus had provision for vigorous agitation 


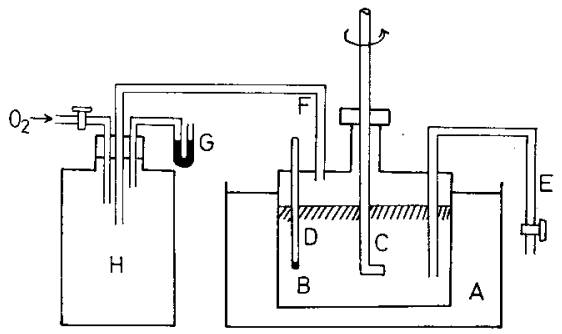

Fig. 1 Experimental apparatus
A : Water bath
$B$ : Reaction vessel
C : Impeller,
$\mathrm{D}:$ Thermometer
E : Sampling tube, $F$ : Gas inlet
$\mathrm{G}:$ Manometer,
$\mathrm{H}$ : Oxygen reservoir

of the reaction mixture at the constant speed of $1000 \mathrm{rpm}$. Gas phase was sucked at the rate of $5 \mathrm{dm}^{3} \mathrm{~min}^{-1}$ untill $10^{-1}$ Torr is achieved. Then pure oxygen gas was allowed to flow into the reaction system. During each test the oxygen partial pressure was maintained at one atm. At given time intervals, $10 \mathrm{~cm}^{3}$ of sample solution was removed and was subjected to chemical analysis. The extent of oxidation was determined by titration to the diphenylamine sulphonate end-point with a standard dichlomate solution.

The activities of hydrogen ion as well as chloride ion were determined by the emf measurements of the following cells:

$\mathrm{H}_{2}$ | test solution | reference electrode

$\mathrm{Ag}-\mathrm{AgCl}$ ! test solution | reference electrode

A silver-silver chloride electrode $(3.33 \mathrm{~mol}$ $\mathrm{dm}^{-3} \mathrm{KCl}$ ) was used as a reference electrode in this study. The hydrogen electrode and the silver chloride electrode were prepared according to the methods described by Ives and Janz $z^{3}$.

The emf measurents were carried out using Takeda Riken-TR-6855 Digital Multimeter. The emf measurements using the above cells should include the liquid junction potential at the junction of the test solution and $3.33 \mathrm{~mol}$ $\mathrm{dm}^{-3} \mathrm{KCl}$ solution of the reference electrode. It is known that the activity of hydrochloric acid increases remarkably with the increase in its concentration ${ }^{4}$. The addition of strong electrolyte to a hydrochloric acid solution changes the activity of hydrochloric acid ${ }^{5}$. In general, the value of liquid junction potential is affec- ted by the concentration of electrolytes added to the solution. However, the magnitude of variation in emf due to the activity change of hydrochloric acid is thought to be far greater than that of liquid junction potential, when the concentrated solutions are subjected for the measurements. Thus we may assume that the ion activities measured using the cells described above is useful for the analysis of autoxidation reaction.

Activities of hydrogen ion and chloride ion were calculated from the following equations:

$$
\begin{aligned}
& \log a_{\mathrm{H}^{+}}=\left(E_{1}+0.206\right) /(2.303 R T / F) \\
& \log a_{\mathrm{Cl}^{-}}=\left(-E_{2}+E_{0}-0.206\right) /(2.303 R T / F)
\end{aligned}
$$

where $E_{1}$ and $E_{2}$ are the observed electromotive forces of cell(a) and cell(b), respectively, and $E_{0}$ is the standard potential of the silver chloride electrode.

\section{Experimental Results and Discussion}

A typical example of rate curves for the autoxidation of $\mathrm{Fe}(\mathrm{II})$ is presented in Fig. 2 as a plot of $\log [\mathrm{Fe}(\mathrm{II})]$ vs. time. The observed linear relationship agrees with the fact that the reaction rate is of first order with respect to $\mathrm{Fe}$ (II) concentration. This relationship was observed in all the kinetic experiments done throughout the present study, thus confirming the results of Posner ${ }^{1)}$. Therefore, at constant temperature, oxygen pressure and

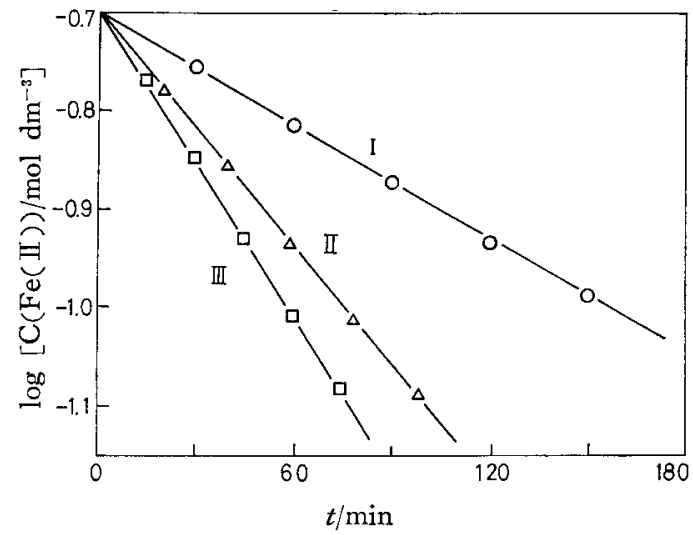

Fig. 2 Typical example of rate curves for the autoxidation of $\mathrm{Fe}$ (II)

$\mathrm{FeCl}_{2}: 0.2 \mathrm{~mol} \mathrm{dm}^{-3}$, Temp. $: 45^{\circ} \mathrm{C}, p_{\mathrm{O}_{2}}: 1 \mathrm{~atm}$, I : $3 \mathrm{~mol} \mathrm{dm}^{-3} \mathrm{HCl}, 2.5 \mathrm{~mol} \mathrm{dm}^{-3} \mathrm{NaCl}$, II $: 4$ $\mathrm{mol} \mathrm{dm}{ }^{-3} \mathrm{HCl}, 2 \mathrm{~mol} \mathrm{dm}^{-3} \mathrm{NaClO}_{4}$, III : $5.5 \mathrm{~mol}$ $\mathrm{dm}^{-3} \mathrm{HCl}$ 


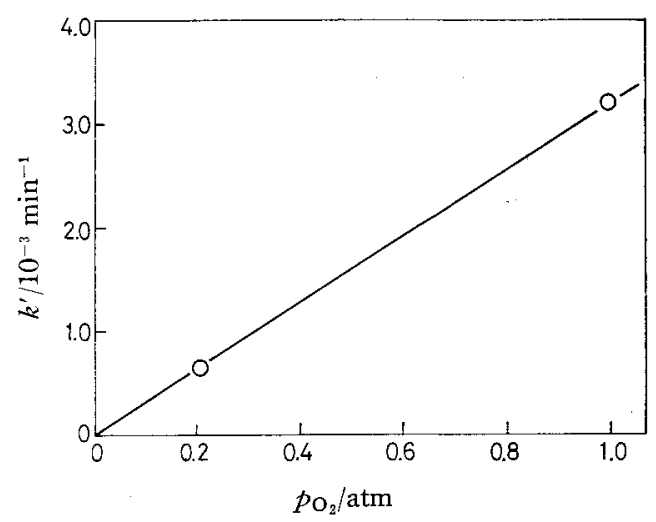

Fig. 3 Effect of oxygen pressure on rate constant $\mathrm{HCl}: 3 \mathrm{~mol} \mathrm{dm}^{-3}, \mathrm{FeCl}_{2}: 0.2 \mathrm{~mol} \mathrm{dm}^{-3}$ $\mathrm{NaCl}: 2 \mathrm{~mol} \mathrm{dm}^{-3}$, Temp. $: 45^{\circ} \mathrm{C}$

hydrochloric acid concentration, we may calculate the rate constant $k^{\prime}$ from the rate equation $-\mathrm{d}[\mathrm{Fe}$ (II) $] / \mathrm{d} t=k^{\prime}[\mathrm{Fe}$ (II) $)$.

To examine the effect of variation in the oxygen partial pressure on the rate constant $k^{\prime}$, the oxidation rates of $\mathrm{Fe}$ (II) were measured at 0.2 and $1.0 \mathrm{~atm}$, in $0.2 \mathrm{~mol} \mathrm{dm}^{-3} \mathrm{FeCl}_{2}$ solution containing $3 \mathrm{~mol} \mathrm{dm}^{-3} \mathrm{HCl}$ and $2 \mathrm{~mol}$ $\mathrm{dm}^{-3} \mathrm{NaCl}$ at $45^{\circ} \mathrm{C}$, and the experimental results are shown in Fig. 3 . This shows that the reaction rate is directly proportional to the oxygen partial pressure. Therefore, at constant temperature and hydrochloric acid concentration, we may calculate the overall second order rate constant $k^{\prime \prime}$ from the rate equation, $-\mathrm{d}[\mathrm{Fe}($ II $)] / \mathrm{d} t=k^{\prime \prime} \cdot[\mathrm{Fe}($ II $)] \cdot p_{\mathrm{O}_{2}}$.

Next, the rate of oxidation reaction was measured at various temperatures with the solutions, whose composition were $0.2 \mathrm{~mol} \mathrm{dm}^{-3}$ $\mathrm{FeCl}_{2}$ and $3 \mathrm{~mol} \mathrm{dm}^{-3} \mathrm{HCl}$, and $0.2 \mathrm{~mol} \mathrm{dm}^{-3}$ $\mathrm{FeCl}_{2}, 3 \mathrm{~mol} \mathrm{dm}^{-3} \mathrm{HCl}$ and $2.5 \mathrm{~mol} \mathrm{dm}^{-3} \mathrm{NaCl}$, respectively, at $1 \mathrm{~atm}$ of oxygen partial pressure. By plotting the logarithm of $k^{\prime \prime}$ value against the reciprocal of the absolute temperature, the Arrhenius plots shown in Fig. 4 were obtained. From the Arrhenius plots, values of 78.2 and $70.7 \mathrm{~kJ} \mathrm{~mol}^{-1}$ were obtained as the apparent activation energies, showing a slight decrease in apparent activation energy by the addition of sodium chloride.

The values of the apparent activation energy obtained in this work are in agreement with the value of $61.1 \mathrm{~kJ} \mathrm{~mol}^{-1}$ determined in $\mathrm{HCl}$

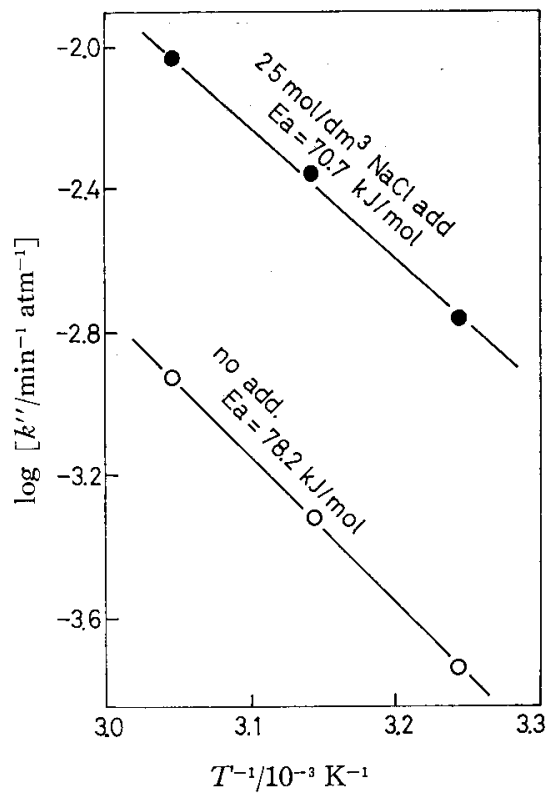

Fig. 4 Effect of temperature on rate constant $\mathrm{HCl}: 3 \mathrm{~mol} \mathrm{dm}^{-3}, \quad \mathrm{FeCl}_{2}: 0.2 \mathrm{~mol} \mathrm{dm}^{-3}$, $p_{\mathrm{O}_{2}}: 1 \mathrm{~atm}$

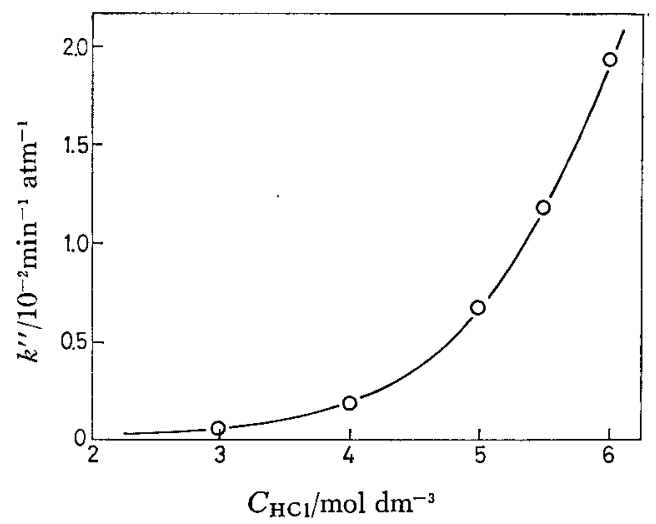

Fig. 5 Effect of $\mathrm{HCl}$ concentration on rate constant

$\mathrm{FeCl}_{2}: 0.2 \mathrm{~mol} \mathrm{dm}{ }^{-3}$, Temp. $: 45^{\circ} \mathrm{C}$, $p_{\mathrm{O}_{2}}: 1 \mathrm{~atm}$

solutions by Posner ${ }^{1)}$, and that of $72.8 \mathrm{~kJ} \mathrm{~mol}^{-1}$ obtained by George ${ }^{6)}$ using perchlorate solutions. These values of activation energv suggest that the chemical reaction controls the overall reaction rate.

Moreover, the rate of oxidation reaction was measured as a function of acidity in the concentration range $3-6 \mathrm{~mol} \mathrm{dm}{ }^{-3} \mathrm{HCl}$. The experimental results are shown in Fig. 5 , in which rate constant, $k^{\prime \prime}$ is plotted against the 
concentration of hydrochloric acid. It was evident from Fig. 5 that the reaction rate increases rapidly and non-linearly with the increase in the hydrochloric acid concentration. In this respect, Yano and his collaborators ${ }^{2)}$ reported that the reaction rate was independent of the hydrogen ion concentration in its range 0.2 $0.8 \mathrm{~mol} \mathrm{dm} \mathrm{m}^{-3}$ as far as the concentration of chloride ion was kept constant, whereas the reaction rate was greatly increased with the increase in chloride ion concentration. Posner ${ }^{1)}$ also found that in $\mathrm{HCl}$ solution at concentrations above $4 \mathrm{~mol} \mathrm{dm}^{-3}$ an extremely rapid autoxidation of ferrous ions set in, and below this $\mathrm{HCl}$ concentration, the reaction was extremely slow. He assumed that in the concentration range of $6-8 \mathrm{~mol} \mathrm{dm}^{-3} \mathrm{HCl}$, reaction rate was proportional to $\left(C_{\mathrm{HCl}}-5.5\right)$ and pointed out that the formation of associated complex $\left[\mathrm{HFe}^{2+} \mathrm{Cl}\right]$ was important to promote the autoxidation. The experimental results shown in Fig. 5 are different in some extent from the conclusion by Posner or by Yano and others.

The concentration of hydrochloric acid used in this work was rather high, so it may be reasonable to use the concept of activity instead of concentration to discuss the role of hydrochloric acid in the autoxidation of $\mathrm{Fe}(\mathrm{II})$. Mean activity coefficients of $\mathrm{HCl}$ at $25^{\circ} \mathrm{C}$ cited in the book of Harned and Owen ${ }^{72}$ were used to calculate the value of $\mathrm{HCl}$ activity.

Rate constant shown in Fig. 5 is then replotted against the activity of hydrochloric acid, and is depicted in Fig. 6. This figure shows that the rate of oxidation is directly propor-

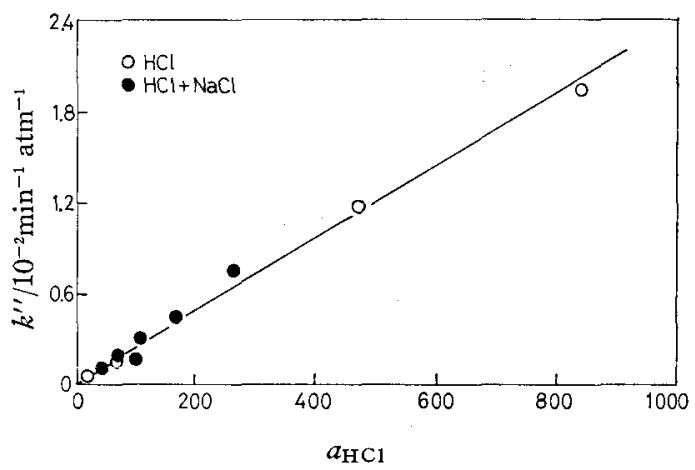

Fig. 6 Effect of $a_{\mathrm{HCl}}$ on rate constant $\mathrm{FeCl}_{2}: 0.2 \mathrm{~mol} \mathrm{dm}^{-3}$, Temp. $: 45^{\circ} \mathrm{C}$, $p_{\mathrm{O}_{2}}: 1 \mathrm{~atm}$ tional to $a_{\mathrm{HCl}}$. In order to examine the generality of this first order dependence, a set of oxidation experiments was done using the ferrous chloride solutions containing hydrochloric acid and sodium chloride.

The mean activity coeffcient of $\mathrm{HCl}$ in a mixed $\mathrm{HCl}-\mathrm{NaCl}$ solution was calculated by using the following equasion ${ }^{8}$ :

$$
\log r_{ \pm}=\log r_{ \pm}^{\circ}-\beta \cdot \mathrm{m}
$$

where $\gamma_{ \pm}$and $r_{ \pm}^{\circ}$ denote the mean activity coefficients of $\mathrm{HCl}$ in mixed solution and in pure $\mathrm{HCl}$ solution, respectively, $\beta$ is the parameter and $\mathrm{m}$ is the molality of $\mathrm{NaCl}$ expressed in mol solute $/ \mathrm{kg}-\mathrm{H}_{2} \mathrm{O}$.

The rate constant for the $\mathrm{HCl}-\mathrm{NaCl}$ mixed solution system is also given in Fig. 6. It is evident that the $k^{\prime \prime}-a_{\mathrm{HCl}}$ plots for the autoxidation of $\mathrm{Fe}(\mathrm{II})$ in $\mathrm{HCl}-\mathrm{NaCl}$ mixed solutions lie on the same straight line obtained for the oxidation of $\mathrm{Fe}(\mathrm{II})$ in $\mathrm{HCl}$ solutions. The figure also indicates that the reaction rate is directly proportional to $a_{\mathrm{HCl}}$ of the solutions in the $\mathrm{HCl}-\mathrm{NaCl}$ mixed solution.

Since hydrochloric acid is a strong electolyte, most of it must dissociate into hydrogen ions as well as chloride ions. Also the activity of $\mathrm{HCl}$ is defined as the product of hydrogen ion activity and chloride ion activity. Under these circumstances, the physical meaning of the first order dependency of rate constant upon $a_{\mathrm{HC1}}$ must be carefully examined.

Reaction rate might be directly concerned with the activity of undissociated $\mathrm{HCl}$, or otherwise it might be the function of the activities of hydrogen ion and/or chloride ion. It is necessary to investigate which would be the case.

The activities of hydrogen and chloride ions in dilute aqueous hydrochloric acid solutions, which contain neutral chloride salt, have been studied considerably in detail ${ }^{5,9}$. However no published data on the activities of hydrogen ion and chloride ion in $\mathrm{HCl}-\mathrm{MCl}_{\mathrm{n}}$ mixed solutions, whose $\mathrm{HCl}$ concentration is over $0.1 \mathrm{~mol}$ $\mathrm{dm}^{-3}$, are available at this stage.

Therefore, the activities of the hydrogen ion and chloride ion in concentrated $\mathrm{HCl}$ solutions containing $\mathrm{NaCl}$ were measured in this work through the emf measurements of the following 


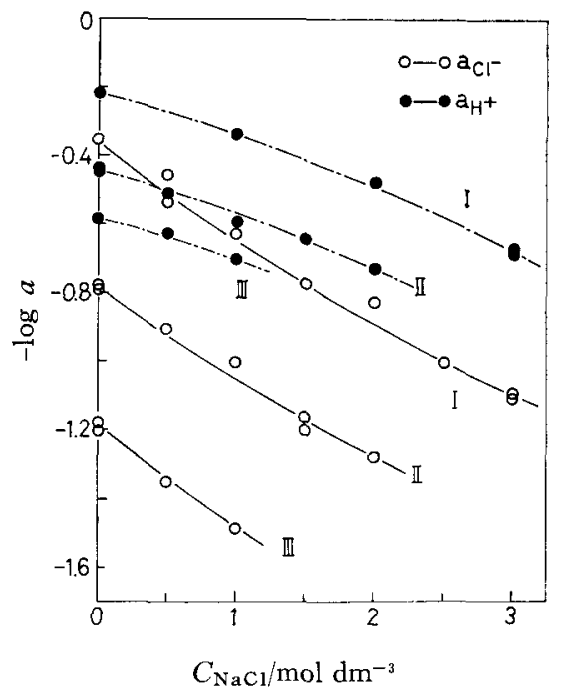

Fig. 7 Effect of $\mathrm{NaCl}$ concentration on activity of $\mathrm{H}^{+}$ion or $\mathrm{Cl}^{-}$ion in $\mathrm{HCl}$ solution at $25^{\circ} \mathrm{C}$

I : $2 \mathrm{~mol} \mathrm{dm}^{-3} \mathrm{HCl}, \quad$ II $: 3 \mathrm{~mol} \mathrm{dm}^{-3} \mathrm{HCl}$

III $: 4 \mathrm{~mol} \mathrm{dm}^{-3} \mathrm{HCl}$

cells at $25^{\circ} \mathrm{C}$ :

$$
\mathrm{H}_{2}\left|\mathrm{HCl}\left(m_{1}\right), \mathrm{NaCl}\left(m_{2}\right)\right| \mathrm{Ag}-\mathrm{AgCl}
$$$$
\text { (3.33 } \mathrm{mol} \mathrm{dm} \mathrm{dm}^{-3} \mathrm{KCl} \text { ) }
$$

$\mathrm{Ag}-\mathrm{AgCl}\left|\mathrm{HCl}\left(m_{1}\right), \mathrm{NaCl}\left(m_{2}\right)\right| \mathrm{Ag}-\mathrm{AgCl}$

(3.33 $\mathrm{mol} \mathrm{dm} \mathrm{dm}^{-3} \mathrm{KCl}$ )

The experimental results are summarized in the forms of $\log a_{\mathrm{H}^{+}}$and $\log a_{\mathrm{Cl}^{-}}$plotted against the concentration of sodium chloride, as shown in Fig. 7. The values of $\log a_{\mathrm{H}^{+}}$as well as $\log a_{\mathrm{Cl}}$-increase with the increase in sodium chloride concentration, with approximately the same slopes for the different concentration of hydrochloric acid.

If the oxidation rate of ferrous ion is of first order with respect to each of $a_{\mathrm{H}^{+}}$and $a_{\mathrm{Cl}^{-}}$, the plot of $\log \left(k^{\prime \prime} / a_{\mathrm{H}^{+}}\right)$vs. $\log a_{\mathrm{Cl}^{-}}$, or $\log$ $\left(k^{\prime \prime} / a_{\mathrm{Cl}^{-}}\right)$vs, $\log a_{\mathrm{H}^{+}}$must lie on a straight line whose slope is unity.

The plot of $\log \left(k^{\prime \prime} / a_{\mathrm{H}^{+}}\right)$vs. $\log a_{\mathrm{Cl}^{-}}$is given in Fig. 8, and the plot of $\log \left(k^{\prime \prime} / a_{\mathrm{Cl}^{-}}\right)$vs. $\log a_{\mathrm{H}^{+}}$is depicted in Fig. 9. Evidently these figures support the assumption of the first order dependency of reaction rate upon $a_{\mathrm{H}^{+}}$as well as $a_{\mathrm{Cl}^{-}}$. Thus, the first order dependency of reaction rate upon $a_{\mathrm{HCl}}$ can now be understood as the first order dependency of reaction rate upon both $a_{\mathrm{H}^{+}}$and $a_{\mathrm{Cl}^{-}}$.

Regarding the effect of hydrochloric acid

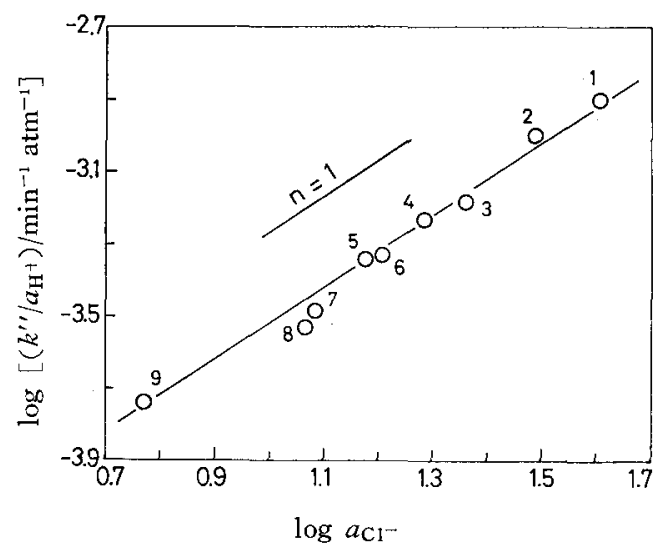

Fig. 8 Relation between $\log \left(k^{\prime \prime} / a_{\mathrm{H}^{+}}\right)$and $\log$ $a_{\mathrm{Cl}^{-}}$

(1) $4 \mathrm{~mol} \mathrm{dm}^{-3} \mathrm{HCl}, 1.5 \mathrm{~mol} \mathrm{dm}^{-3} \mathrm{NaCl}$

(2) $4 \mathrm{~mol} \mathrm{dm}^{-3} \mathrm{HCl}, 1 \mathrm{~mol} \mathrm{dm}{ }^{-3} \mathrm{NaCl}$

(3) $3 \mathrm{~mol} \mathrm{dm}^{-3} \mathrm{HCl}, 2.5 \mathrm{~mol} \mathrm{dm}^{-3} \mathrm{NaCl}$

(4) $3 \mathrm{~mol} \mathrm{dm}^{-3} \mathrm{HCl}, 2 \mathrm{~mol} \mathrm{dm}{ }^{-3} \mathrm{NaCl}$

(5) $3 \mathrm{~mol} \mathrm{dm}^{-3} \mathrm{HCl}, 1.5 \mathrm{~mol} \mathrm{dm}^{-3} \mathrm{NaCl}$

(6) $4 \mathrm{~mol} \mathrm{dm}^{-3} \mathrm{HCl}$

(7) $2 \mathrm{~mol} \mathrm{dm}^{-3} \mathrm{HCl}, 3 \mathrm{~mol} \mathrm{dm} m^{-3} \mathrm{NaCl}$

(8) $3 \mathrm{~mol} \mathrm{dm}^{-3} \mathrm{HCl}, 1 \mathrm{~mol} \mathrm{dm}{ }^{-3} \mathrm{NaCl}$

(9) $3 \mathrm{~mol} \mathrm{dm}^{-3} \mathrm{HCl}$

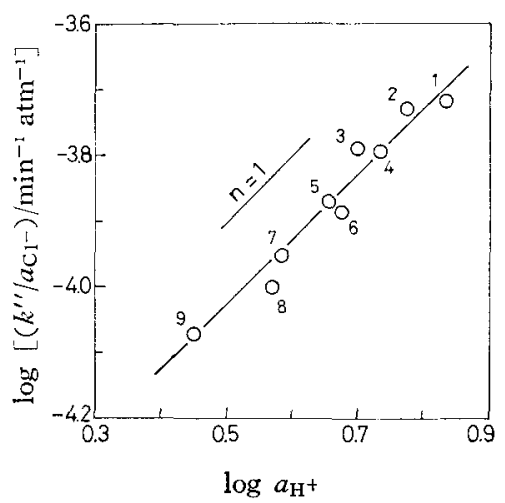

Fig. 9 Relation between $\log \left(k^{\prime \prime} / a_{\mathrm{Cl}^{-}}\right)$and $\log a_{\mathrm{H}^{+}}$

(1) $3 \mathrm{~mol} \mathrm{dm}{ }^{-3} \mathrm{HCl}, 2.5 \mathrm{~mol} \mathrm{dm} \mathrm{dm}^{-3} \mathrm{NaCl}$

(2) $4 \mathrm{~mol} \mathrm{dm}^{-3} \mathrm{HCl}, 1.5 \mathrm{~mol} \mathrm{dm}-3 \mathrm{NaCl}$

(3) $4 \mathrm{~mol} \mathrm{dm}^{-3} \mathrm{HCl}, 1 \mathrm{~mol} \mathrm{dm} m^{-3} \mathrm{NeCl}$

(4) $3 \mathrm{~mol} \mathrm{dm}^{-3} \mathrm{HCl}, 2 \mathrm{~mol} \mathrm{dm} \mathrm{m}^{-3} \mathrm{NaCl}$

(5) $3 \mathrm{~mol} \mathrm{dm}^{-3} \mathrm{HCl}, 1.5$ moldm $\mathrm{m}^{-3} \mathrm{NaCl}$

(6) $2 \mathrm{~mol} \mathrm{dm}^{-3} \mathrm{HCl}, 3 \mathrm{~mol} \mathrm{dm}{ }^{-3} \mathrm{NaCl}$

(7) $4 \mathrm{~mol} \mathrm{dm}^{-3} \mathrm{HCl}$

(8) $3 \mathrm{~mol} \mathrm{dm}^{-3} \mathrm{HCl}, 1 \mathrm{~mol} \mathrm{dm} \mathrm{dm}^{-3} \mathrm{NaCl}$

(9) $3 \mathrm{~mol} \mathrm{dm}^{-3} \mathrm{HCl}$

concentration, Posner ${ }^{1)}$ concluded that the rate had first order dependence on hydrochloric acid concentrations above $5.5 \mathrm{~mol} \mathrm{dm}^{-3}$. On 
the other hand, Yano et al. ${ }^{2)}$ stated no influence of hydrogen ion concentration in dilute hydrochloric acid solution and they observed a remarkble rate enhancement by chloride addition. The present authors' results of the first order dependencies of the reaction with respect to each of hydrogen ion activity and chloride ion activity are quite diffetent from the conclusions of previous investigations. However it might be possible to analyze the experimental results by Posner or by Yano et. al. according to the same method of this study without any controversy.

As mentioned before, we observed that the rate is first order with respect to the concentration of $\mathrm{Fe}(\mathrm{II})$, and this may suggest that the ratio of the activity coefficient, $\gamma_{\mathrm{Fe}^{2}}+/ \gamma_{\mathrm{HFeCl}^{2+}}{ }^{2}$, stays almost constant during the oxidation reactions.

To interpret the results obtained in this work, the following oxidation mechanism involving chain reactions is proposed:

$$
\begin{aligned}
& \mathrm{Fe}^{2+}+\mathrm{Cl}^{-} \stackrel{K_{1}}{\rightleftharpoons} \mathrm{FeCl}^{+} \\
& \mathrm{FeCl}^{+}+\mathrm{H}^{+} \stackrel{K_{2}}{\rightleftharpoons} \mathrm{HFeCl}^{2+} \\
& \mathrm{HFeCl}^{2+}+\mathrm{O}_{2} \\
& \stackrel{k_{0}}{\longrightarrow} \mathrm{FeCl}^{2+}+\mathrm{HO}_{2} \quad \text { (initiation) }(6) \\
& \mathrm{HFeCl}^{2+}+\mathrm{HO}_{2} \\
& \stackrel{\text { fast }}{\longrightarrow} \mathrm{FeCl}^{2+}+\mathrm{H}_{2} \mathrm{O}_{2} \quad \text { (propagation) }(7) \\
& \mathrm{HFeCl}^{2+}+\mathrm{H}_{2} \mathrm{O}_{2} \\
& \stackrel{\text { fast }}{\longrightarrow} \mathrm{FeCl}^{2+}+\mathrm{H}_{3} \mathrm{O}_{2}(\text { " ) }(8) \\
& \mathrm{HFeCl}^{2+}+\mathrm{H}_{3} \mathrm{O}_{2} \\
& \stackrel{\text { fast }}{\longrightarrow} \mathrm{FeCl}^{2+}+2 \mathrm{H}_{2} \mathrm{O} \text { (termination) (9) }
\end{aligned}
$$

where $K_{1}$ and $K_{2}$ are the equilibrium constants for the reactions (4) and (5), respectively, and $k_{0}$ is the rate constant for the reaction (6). The above mechanism is similar to the one proposed by Cher and Davidson ${ }^{10}$ ) for the autoxidation reaction of ferrous ion in aqueous phosphoric acid solutions.
Rate equation which satisfies both the experimental results and the mechanism proposed above, can be expressed by eqs. (10)

$$
\begin{aligned}
R & =k \cdot\left[\mathrm{HFeCl}^{2+}\right] \cdot p_{\mathrm{O}_{2}} \\
& =k_{0} K_{1} K_{2} \cdot a_{\mathrm{H}^{+}} \cdot a_{\mathrm{Cl}^{-}} \cdot\left[\mathrm{Fe}^{2+}\right] \cdot p_{\mathrm{O}_{2}}
\end{aligned}
$$

The concentration of the species $\mathrm{HFeCl}^{2+}$ is thought to be controlled by the activities of hydrogen ion and chloride ion.

\section{Conclusion}

The oxidation reaction of $\mathrm{Fe}(\mathrm{II})$ in aqueous hydrochloric acid solutions by dissolved molecular oxygen is controlled by chemical reaction steps. It is considered that the second order reaction holds between $\mathrm{HFeCl}^{2+}$ and dissolved $\mathrm{O}_{2}$ under the experimental condition studied. The concentration of the former species is determined by the activities of both hydrogen ion and chloride ion.

\section{Acknowledgements:}

The authors wish to thank to Dr. Y. Awakura for his valuable discussions to our present study.

〈E 588〉 (Received Oct. 23, 1978)

\section{References:}

1) A.M. Posner, Trans. Faraday. Soc. 49, 382 (1953).

2) T. Yano, T. Suetaka, T. Umehara, K. Konishi and A. Horiuchi, Nippon Kagaku Kaishi No. 8, 1375 (1974).

3) D.J.G. Ives and G.J. Janz, "Reference Electrodes", p. 71, p. 179 (1961), Academic Press, Ncw York and London.

4) G.N. Lewis and M. Randall, "Thermodynamics", p. 316, (1961), McGraw-Hill, New York.

5) T. Takahashi, Boshoku Gijutsu 23, 625 (1974).

6) P. George, J. Chem. Soc. 4349 (1954).

7) H.S. Harned and B.B. Owen, "The Physical Chemistry of Electrolytic Solutions", p. 716 (1958), Reinhold Publishing Co., New York.

8) H.S. Harned and B.B.Owen, ibid. p. 600 (1948).

9) K. Schwabe, Electrochim. Acta 12, 67 (1967).

10) M. Cher and N. Davidson, J. Amer. Chem. Soc. 71, 793 (1955). 